\title{
International Perspective to Protect the Human Rights of Religious Minorities-A Critical Study
}

\author{
A NarayanaSwamy \\ Assistant Professor of Law \& Research Scholar, Vidyodaya Law College, Tumkur.
}

"You must not lose faith in Humanity. Humanity is an Ocean, if a few drops of the Ocean are dirty, the Ocean does not become dirty------------- Mahatma Gandhi.

\section{Introduction:}

Human Rights being essential for all-round development of the personality of individuals in society, be necessarily protected and be made available to all the individuals. Human rights are Natural Rights, Basic Rights, Universal Rights and Legal Rights, which are universally applicable to all without any discrimination based on Sex, Race, Religion and Region. But groups of numerically small which cannot protect them due to domination of majority and exploitation. Therefore, they need international and national legal support to protect their human rights. Human rights are legal rights because it involves the implementation of rights and obligations mentioned in international treaties and it is the corresponding duty of the state to protect the rights of human beings. Declaration of the Human rights Defenders adopted by the General Assembly on December $9^{\text {th }}$ 1998 laid down under Article 2, Para 1, states that each state has the prime responsibility and duty to protect, promote and implement all human rights by adopting necessary measures. Para 2 of the above Article states that each state shall adopt necessary legislative, administrative and other steps to ensure that the right to protect human rights effectively guaranteed in it..

\section{What are the Human Rights?}

The Rights, which are declared in Universal Declaration of Human Rights and other International Declarations and Covenants like Civil and Political Rights and Economic Social and Cultural Rights enumerated the basic postulates and principles of human rights in the most comprehensive manner such as Right to life, Freedom from inhuman and degrading treatment, freedom from slavery, Right to liberty and Security, Equality before Law, Right against all kinds discrimination, Freedom of association and assembly, Right to Nationality, Right to Education, Right to Environment, Right to Work, Right to Participate in Government, Right to Family and Marriage etc... are some of the important human rights.

Section 2 (d) of the Protection of Human Rights Act, $1993^{1}$, defined the expression of human rights by stating that human rights means the rights relating to life, liberty, equality and dignity of the individuals guaranteed by the Constitution or embodied in the International Covenants and enforced by courts in India.

\section{Who are Religious minorities under international law?}

Almost all States in the world have one or more type of minority groups within their national territories, characterized by their own national, ethnic, linguistic or religious identity, which differs from that of the majority population. There is no internationally agreed definition as to which groups constitute minorities, but the term minority as used in the United Nations human rights system usually refers to national or ethnic, religious and linguistic minorities, pursuant to the United Nations Minorities Declaration. ${ }^{2}$

According to a definition offered in 1977 by Francesco Capotorti, Special Rapporteur of the United Nations Sub-Commission on Prevention of Discrimination and Protection of Minorities, ${ }^{3}$, a minority is "A group numerically inferior to the rest of the population of a State, in a non-dominant position, whose members being nationals of the State possess ethnic, religious or linguistic characteristics differing from those of the rest of the population".

\footnotetext{
${ }^{1}$ Protection of Human Rights Act, 1993

${ }^{2}$ Minorities and minority rights, journal of the Indian Law Institute, volume 47, January-March 2005, Number1

${ }^{3}$ Special Rapporteur of the United Nations Sub-Commission on Prevention of Discrimination and

Protection of Minorities
} 
Article 1 of the Declaration on the Rights of Persons belonging to National or Ethnic, Religious or Linguistic Minorities, 1992, refers the existence of National or Ethnic, Cultural, Religious and Linguistic identify of minorities are to be protected within their respective territories by laws and other measures. So that, Religious Minorities are those minorities which come under the concept of minorities as per the above Declaration ${ }^{4}$

\section{Problems of Religious Minorities across the world:}

Generally, Religious Minority groups are numerically small in size of population being faced a number of problems such as lack of equal opportunities in society, discrimination, exploitation, attacks against them, lack of protection, communal violence and riots, lack of proper representation in Civil Services and politics, problem of separation, cultural problems, linguistic and educational problems, sexual harassment, poverty and backwardness etc. are major problems of religious minorities across the world ${ }^{5}$. Besides, there was the grave violation of human rights of religious minorities during the First and Second World Wars.

\section{International Human Rights Law and the Protection of Human Rights of Religious Minorities:}

Sources of International human rights are International Conventions and Regional Conventions, International Customs, International Instruments, Judicial decisions and official documentations etc... Play a vital role to protect human rights at International and Region level.

\section{League of Nations and the protection of Human rights of minorities:}

After the First World War, minority issues became a central concern for the League of Nations. So that, the first significant attempt to identify internationally recognized minority rights was through a number of minority treaties adopted under the auspicious of the League of Nations. The major protection were the right to equality and non-discrimination, the right to citizenship, the right to use one's own language in public and private, the right to establish their own religious, cultural charitable and educational institutions and an obligation on the state to provide an equitable level of financial support to minority schools, instruction at the primary level would be in the minority's mother tongue and entrenchment of laws protecting minorities. So that, they could not be changed by subsequent status. But the supervisory system established by the League was political rather than legal and it did not permit aggrieved minorities to engage

States on an equal. Finally, the League of Nations was totally failed to protect the rights of religious minorities legally.

\section{Emergence of the United Nations and the Protection of Human Rights of religious minorities:}

Following the Second world war, the United Nations Organization was emerged as an International body on $24^{\text {th }}$ October, 1945 , in the direction to maintain international peace, co-operation and to protect the human rights of people of all nations and all religions of the world.

\section{United Nations Charter and the Human Rights of Religious Minorities:}

The Charter of the United Nations does not mention about minority rights per se, but it does include several provisions on human rights, Article 1(3) identifies as one of the purposes of the United Nations is the achievement of international co-operation in promoting and encouraging respect for human rights and fundamental freedoms for all without distinction as to race, sex, language and religion ${ }^{6}$.

\section{Universal Declaration of Human Rights and Religious Minorities:}

It is the First and foremost important International Declaration on Human Rights adopted by the General Assembly on $10^{\text {th }}$ December, 1948, which articulated the content of human rights in much greater detail and remains one of the most important international human rights documents. The preamble of Universal Declaration of Human Rights incorporates a form of natural law language by inserting "whereas recognition of the inherent dignity and of the equal and inalienable rights of all members of the human family is the foundation of freedom, justice and peace in the world". But the General Assembly was unable to agree on any formulation in the Declaration concerning minority rights per se and it was difficult to adopt a uniform solution for this complex and delicate question which has special aspects in each state in which it arises. It sets out, for the first time, fundamental human rights to be universally applicable and protected without discrimination based on Sex, Race, Religion, Ethnic, and Language.

\footnotetext{
${ }^{4}$ Dr.H.O. Agarwal, Human Rights, Central Law Publications, Allahabad-2

${ }^{5}$ Prof ,Dr, P. Ishwara Bhat, Law and Social Transformation, Eastern Book Company, Lucknow

${ }^{6}$ Article 1 of the Charter of United Nations
} 


\section{Convention on the prevention and punishment of the Crime of Genocide 1948:}

The United Nations of the General Assembly adopted the Convention on the Prevention and Punishment of the Crime of Genocide on $9^{\text {th }}$ December, 1948, which came into force on January $12^{\text {th }}, 1951$. Genocide means killing of a group of human beings based on groups. Accordingly the contracting parties confirm that Genocide committed whether in time of peace or in time of war, is a crime under International law which they under take to prevent and to punish it. It prohibits the destruction of a National, Ethnical, Racial and Religious groups ${ }^{7}$. The Convention provided that the Contracting parties shall enact necessary legislation to provide effective penalties.

\section{Convention against Discrimination in Education:}

The UNESCO Convention against Discrimination in Education, adopted on $14^{\text {th }}$ December, 1960 and entered into force 22 May 1962, is the first international convention which contains provisions relating to the rights of persons belonging to minorities, including linguistic minorities. Article 1, of the Convention States that, the "discrimination" includes any distinction, exclusion, limitation or preference which, being based on race, colour, sex, language, religion, political or other opinion, national or social origin, economic condition or birth, has the purpose or effect of nullifying or impairing equality or treatment in education. Article 5 (1) states that, State Parties to this Convention agree that it is essential to recognize the right of members of national minorities to carry on their own educational activities, including the maintenance of schools and, depending on the educational policy of each State, the use of the teaching of their own language.

\section{International Convention on the Elimination of All Forms of Racial Discrimination:}

The General Assembly on $21^{\text {st }}$ December, 1965, adopted this convention on the Elimination of all Forms of Racial Discrimination which came into force on $4^{\text {th }}$ January, ' 1969 . Accordingly, Article 2 states that, state parties condemn racial discrimination and undertake to pursue by all appropriate and without delay a policy of eliminating racial discrimination in all its forms. Each state party undertakes to engage in no act or practice of racial discrimination against persons, groups of persons or institutions and to ensure that all public authorities and public institution, national and local, shall act in conformity with this obligation. The rights included in this convention are the right to freedom of thought, conscience and religion, the right to freedom of opinion and expression and the right to freedom of peaceful assembly and association ${ }^{8}$.

\section{International Covenant on Civil and political Rights and Rights of Minority:}

The General Assembly on $19^{\text {th }}$ December, 1966, by resolution adopted the International Covenant on Civil and political rights, which came into force on $23^{\text {rd }}$ March 1976. Article 27 of the Convention states about specific provision concerned with minorities. Accordingly, the States in which ethnic, religious or Linguistic minorities exist, persons belonging to such minorities shall not be denied the right, in community with the other members of their group, to enjoy their own culture, to profess and practice their own religion, or to use their own language. It is the legal obligation of the state parties to protect and implement the provisions for the minorities at their nationals?.

In the case of Antonina Ignatane v. Latvia-Politics ${ }^{10}$ : A case was brought before the Human Rights Committee of the United Nations under Article 25 guarantees every citizen the right and the opportunity to be elected at genuine periodic elections without any of the distinctions mentioned in Article2,including language.

\section{UN Declaration on the Rights of Persons belonging to National or Ethnic, Religious and Linguistic Minorities:}

The General Assembly on $18^{\text {th }}$ December, 1992, adopted this Declaration recognizing the need to ensure more effective implementation of international human rights instruments with regard to the rights of persons belonging to national or ethnic, religious and linguistic minorities ${ }^{11}$ and includes

Article 1, (1) states that, states shall protect the existence of national or ethnic, cultural, religious and linguistic identity of minorities within their respective territories and shall encourage conditions for the promotion of that identity and (2) states shall adopt appropriate legislative and other measures to achieve those ends.

Article 2, (1) Persons belonging to national or ethnic, cultural, religious and linguistic minorities have the right to enjoy their own culture, to profess and practice their own religion and to use their own language, in private and in public freely and without interference or any form of discrimination, (2) they have right to participate

\footnotetext{
${ }^{7}$ General Assembly Resolution Nó 1021, December9, 1948

${ }^{8}$ General Assembly Resolution No 2106A (XX) of 21 December 1965.

${ }^{9}$ General Assembly Resolution No 2200A (XXI) of 16 December, 1966.

${ }^{10}$ Antonina Ignatane v. Latvia, CCPR/C/72/D/884/1999

${ }^{11}$ General Assembly Resolution No A/RES/47/135, $92^{\text {nd }}$ Plenary meeting, $18^{\text {th }}$ December, 1992.
} 
effectively in cultural, religious, social, economic and public life, (3) they have right to participate effectively in decisions on national and where appropriate, regional level

Article 3, states that they have rights individually as well as in community with other member of their group, without any discrimination.

Article4, states that they may exercise fully and effectively all their human rights and fundamental freedoms without any discrimination and in full equality before the law.

Articel5, National policies and programmes shall be planned and implemented with due regard for the legitimate interests of persons belonging to minorities.

Articel6, states that states should cooperate to minorities interalia, exchanging information and experiences, in order to promote mutual understanding and confidence.

Article 7, states should cooperate in order to promote respect for the rights set forth in the present Declaration.

Article 8, State shall fulfill in good faith the obligations and commitments they have assumed under international treaties and agreements to which they are parties.

Article 9, the specialized agencies and other organizations of the United Nations system shall contribute to the full realization of the rights and principles set forth in the present Declaration, with in their respective fields of competence.

The working group on Minorities of the UN Sub-commission on Human Rights, which is described in pamphlet No.2, provides an opportunity for those concerned with minority rights to review the practical realization of the UN Declaration on Minority Rights ${ }^{12}$.

\section{Regional Conventions and Protection of Minority Rights:}

The United Nations in the Charter gave due importance to regional arrangements. Chapter VIII of the Charter consisting of Article 52 to 54 is devoted exclusively to regional arrangements for dealing with matters relating to maintenance of international peace and security provided that the activities of such arrangements are consistent with the purposes and principles of the United Nations Charter. The Vienna Conference on Human rights in $1993^{13}$ stated in the Declaration that Regional arrangements play a fundamental role in promoting and protecting Human Rights. So that, a number of Regional conventions have been adopted in this direction, they are as follows.

\section{The Inter-American Human Rights System and Protection of Minority rights:}

To protect the human rights effectively at regional level, The Organization of American States was founded in 1948, and all of the OAS members are bound by the OAS Charter and the American Declaration on the Rights and Duties of Man was adopted in 1948, then in 1969, the American convention on Human Rights was adopted, the Inter-American convention to prevent and punish Torture was adopted in 1985, the InterAmerican Convention on Forced Disappearance of persons was adopted in 1994 etc... adopted by the OAS related with minorities rights ${ }^{14}$. The Inter-American Commission on Human Rights was created in 1959 to monitor on Human Rights with seven elected members by the General Assembly of OAS. The main functions of the Commission are to promote, respect and protect human rights.

\section{The American Convention on Human Rights and Minority Right:}

The American Convention on Human Rights was adopted on2 November, 1969, which came into force on 11 July, 1978, which is included both Civil and Political rights and Economic, Cultural and Social Rights. Accordingly Article 12 of the Convention states that everyone has the right to Freedom of Conscience and Religion. To implement the human rights successfully, the Inter-American Court of Human rights was created in 1979 with seven judges.

\section{The American Convention to Prevent and Punish Torture:}

The American Convention to prevent and Punish Torture was adopted in 1985, accordingly no one shall be subjected to torture or to cruel inhuman, or degrading punishment or treatment and the states parties shall take effective measures to prevent and punish torture within their jurisdiction. They shall also take effective measures to prevent and punish other cruel, in human or degrading treatment or punishment within their jurisdiction.

\footnotetext{
${ }^{12}$ Pamphlet No.2 of the UN Guide for Minorities.

${ }^{13}$ World conference on Human Rights 14-25 June, 1993, Vienna, Austria.

${ }^{14}$ Pamphlet Nọ: 5 of the U.N.Guide for Minorities.
} 


\section{European Convention on Human Rights and Minority Rights}

In the European Region, the European Council adopted the European Convention on Human Rights was adopted in 1950, which came into force on $3^{\text {rd }}$ September; 1953, accordingly Section 1, Article 9 states that, the Right to Freedom of thought, conscience and religion. Section III of the Convention had provided the provision for the European Commission on Human rights and the European Court of Human Rights, which came into force on $3^{\text {rd }}$ September, $1958^{15}$.

In the case of Skender v. the Former Yugoslav Republic of Macedonia ${ }^{16}$ : In February 1997, the applicant asked the Turkish speaking school to admit his elder daughter, but the school refused to enroll his elder daughter, as they did not live in the district of the School. He started proceeding before the Supreme Court as per Article 14 of Convention in conjunction with 2 of ProtocolNo.1 and the Supreme Court refused on procedural grounds, to examine the applicant's complaint in respect of the school's refusal.

\section{African Charter on Human and Peoples' Rights:}

The African Charter was adopted on $27^{\text {th }}$ July, 1981 and entered into force on $21^{\text {st }}$ October, 1986, the Charter stipulates rights as well as duties of individuals and established a commission to promote human and peoples' rights and ensure their protection in Africa. The Charter also provided an implementation machinery under Article 67, and the African Court on Human and peoples' Rights was established by adopting a protocol to the African Charter on Human and Peoples' Rights on $9^{\text {th }}$ June, 1998 and the protocol came into force on $24^{\text {th }}$ January, 2004. But, yet there is no separate convention at Asian and Arabic regions to protect and promote the human rights of all and particularly religious minorities.

\section{Criticism:}

Even though, the United Nations Organization has adopted several international declaration and conventions, violations of minority rights constitute today a wide scale problem and affecting all regions of the world, attacks against religious minorities and systematic exclusion of minorities from decision making Almost all countries in the world, individuals were subjected to discrimination, violence and abuse, perpetrated and sanctioned violence for simply exercising their faith, identifying with a certain religion. Democratic and Secular Countries are failed to provide Security and equal opportunities to religious minorities.

The situation of religious minorities in Asia continues to be extremely challenging, as many groups endure the reality of physical harassment and social, economic and political exclusion.

In Pakistan, there is the serious violation of human rights of religious minorities and attacks against minority Shias and Christian's common.

In Bangladesh attacks and harassment against Hindu minorities and other ethnic and Religious Minorities In Sri Lanka Violent Buddhist nationalist groups destroyed mosques and churches.

Increases of mosque attacks in the United Kingdom,

Both Shia Muslims and Christians faced violent and deadly attacks in Egypt, Anti-Muslim violence in Meikhtila, Burma, led to up to 100 deaths and an estimated 12,000 displaced residents from the area and Islamist led mobs and organized groups attacked churches and Christian-owned homes and businesses and then looted properties in early 2013.

In Iraq, there were reports of societal abuses and discrimination based religious affiliation.

In India, the condition of the religious minorities continuous to be very complex and critical. Due to serious continuous communal riots and violence, against Muslims, Christians and Sikhs they are not able to integrate properly in the society. After the assassination of the Smt. Indira Gandhi in 1984 anti-Sikhs targets increased and thousand together were burnt alive and suffered massive property damage and became displaced persons. In the aftermath of the destruction of the Babri Mosque in Ayodhya on $6^{\text {th }}$ December 1992, riots took place between Hindus and Muslims in the city of Mumbai. Then in 2002 Gujarat riots 790 Muslims and 254 Hindus were killed in an act of retaliation ${ }^{17}$. In recent days, there has been a sharp increase in violent attacks on Christians in India. Clashes in the Muzaffarnagar district in Uttar Pradesh between Hindu and Muslim communities led to 65 deaths and 68 persons injured and it is estimated nearly 40,000 people were displaced.

\section{Governments Repression of Religious Freedom:}

Governments from all regions subjected to members of religious groups to repressive policies, discriminatory laws, discriminatory application of laws and prohibitions on conversion which not only infringed on freedom of religion but they also often created a permissive environment for broader human rights abuses.

\footnotetext{
${ }^{15}$ Minority Rights: International Standards and Guidance for Implementation, UN, New York and Geneva,20120.

${ }^{16}$ Skender v. Former Yugoslav Republic of Macedonia,

17 Human Rights Watch, Vol-14, N0:3 (c) April 2002
} 
Countries such a s Saudi Arabia, Iran and Sudan put severe restrictions on members of religious groups that did not confirm to the state approved religions on the otherhand, in China,Cuba,Tajikistan, Turkmenistan and Uzbekistan religious activity was only lawful if explicitly authorized by the state. Some examples as follows,

In Saudi Arabia, the public practice of any religion other than Islam is prohibited and freedom of religion is neither recognized nor protected under the law and no public places of worship for non-Muslims exist.

In North Korea again stood out for its absolute prohibition of religious organizations and harsh punishments for any unauthorized religious activities.

In Pakistan, the authorities continue to enforce blasphemy laws and laws designed to marginalize the Ahmadiyya Muslim Community.

\section{Suggestions and Conclusion}

After analyzing the above facts, the researcher has made the following suggestions,

- It shall be required to adopt a Separate International Convention on Religious Minorities.

- It shall be required to adopt a separate regional level convention, Asian convention on Human Rights, with commission and separate court immediately at Asian region.

- It shall be required another separate regional Arabic convention on Human Rights

- International forums would pressurize on states parties to make legal provision at their local laws relating to Internal Security laws and doing away with practices like illegal detention and torture while in detention.

- It shall be required to establish separate commissions and courts at regional level to monitor and decide the cases relating to abuse of rights of religious minorities.

- States must provide opportunities to the religious minorities to participate effectively in Governments through politics and appropriate efforts to make separate reservations in politics.

\section{Conclusion:}

Based on the above discussion, the researcher concluded that, the Religious Minorities are also Human beings and they are also part of the society, individuals should treat them as human beings not as enemies. State parties shall take all precautionary measures for their social, economic, educational, cultural and political development by adopting legislative and Administrative measures. At the same time, there shall be adopted immediately Asian and Arabic regional level conventions on Human Rights. Finally there shall be a separate and effective International mechanism and Instruments to protect the human rights of religious minorities across the world.

"No democracy can long survive which does not accept as fundamental to its very existence the recognition of the rights of minorities" --- Franklin D. Roosevelt 